\title{
Role of Combined Pleural Fluid Cholesterol and Total Protein in Differentiation of Exudates and Transudates
}

\author{
Anupam Bista ${ }^{1}$, Suman Thapa ${ }^{2}$, Prashant Subedi ${ }^{2}$, Kiran Manandhar ${ }^{l}$ \\ ${ }^{1}$ Department of Internal Medicine, Bir Hospital, National Academy of Medical Sciences, Kathmandu, Nepal \\ ${ }^{2}$ Department of Internal Medicine, Patan Academy of Health Sciences, Lalitpur, Nepal
}

\begin{abstract}
Introduction: Light's criteria had been the standard method for distinguishing exudative and transudative pleural effusions which misidentify $15-20 \%$ of transudates as exudates. This study aims to find out the role of combined pleural fluid cholesterol and total protein in distinguishing exudative from transudative pleural effusions and its applicability in Nepalese populations.

Materials and Methods: Patients with pleural effusions were enrolled for the study. The combined pleural fluid cholesterol and total protein were compared with Light's criteria and also compared with the diagnosis on discharge to find out their usefulness in categorizing the pleural effusions.

Results: A total of 81 patients enrolled in the study, $42(51.9 \%)$ were male. Based on Light's criteria, $88.8 \%$ pleural effusions were found to be exudates and $11.1 \%$ were found to be transudates. Within the criteria, Light's criteria categorized more pleural fluids as exudates than the diagnosis on discharge. Based on pleural fluid cholesterol $>60 \mathrm{mg} / \mathrm{dL}$ and protein $>3 \mathrm{~g} / \mathrm{dL}$ for the classification of exudative and transudative pleural fluid, $62.9 \%$ out of 81 samples felled under the exudates and $37.03 \%$ pleural effusions under transudates with the sensitivity $87.9 \%$ and specificity $100 \%$.
\end{abstract}

Conclusions: Though Light's criteria remain the gold standard to differentiate transudates and exudates, combined pleural fluid cholesterol and total protein give nearly comparable results without the need for simultaneous blood investigations.

\section{Correspondence:}

Dr. Anupam Bista, MBBS, MD

Department of Internal Medicine

Bir Hospital, National Academy of Medical Sciences, Kathmandu, Nepal

ORCID ID: 0000-0002-7892-9296

Email: anupambista@gmail.com

Submitted: $5^{\text {th }}$ April 2020

Accepted: $18^{\text {th }}$ June 2020

Source of Support: None

Conflict of Interest: None

Citation: Bista A, Thapa S, Subedi P, Manandhar K Role of combined pleural fluid cholesterol and total protein in differentiation of exudates and transudates. NMJ 2020;3(1):282-5.DOI 10.3126/nmj.v3i1.28330

Keywords: Exudates; Light's criteria; Pleural effusion; Transudates

\section{INTRODUCTION}

Fluid enters the pleural space from the capillaries in the parietal pleura, interstitial spaces of the lungs via the visceral pleura, and from the peritoneal cavity through channels in the diaphragm. It is removed via the lymphatics in the parietal pleura. Pleural fluid accumulates when pleural fluid formation exceeds its absorption or due to blockade of lymphatics. The first step in diagnosis is to differentiate whether it's transudative or exudative pleural effusion. ${ }^{1}$
Light's criteria have been universally accepted than any other criteria for differentiating transudative and exudative effusion with sensitivity and specificity of $99 \%$ and $98 \%$ respectively. ${ }^{2}$ The main disadvantage of Light's criteria is that they identify $15-20 \%$ of transudative as exudative pleural effusions especially in congestive heart failure patients receiving diuretics. ${ }^{3}$ Pleural cholesterol levels have been explored for their usefulness in differentiating transudative and exudative effusion with less 
misclassification than any of the light's parameters. ${ }^{4}$ Several studies suggest that pleural cholesterol is increased in pleural exudates, making it a potential biomarker for differentiating exudative and transudative pleural effusions., ${ }^{4,5}$ Cellular degeneration (leukocytes and erythrocytes) and vascular leakage due to increased permeability are thought to elevate pleural cholesterol levels. However, elevated cholesterol levels in exudative effusions seem to be independent of serum levels. ${ }^{5}$ Using combined pleural fluid cholesterol and total protein for differentiation of transudative and exudative effusion, a study done in India, showed sensitivity and specificity of $100 \%{ }^{6}$

Differentiating pleural effusion as transudative or exudative is still difficult using a single criterion. Light's criteria need measurements of 4 biochemical measures for differentiation of transudative and exudative effusions which could be difficult, costly, and need for simultaneous blood sampling at the same time. In the meantime, it misclassifies $15-20 \%$ of transudative effusions to exudates. To simplify the diagnostic procedure and omitting the need for simultaneous blood sampling, we examine whether comparable results could be obtained using pleural fluid cholesterol and total protein. This study aimed to compare combined pleural fluid cholesterol and total protein with Light's criteria and find its significance.

\section{MATERIALS AND METHODS}

This was an observational study conducted in the tertiary level hospital of Nepal. The study was conducted in the Department of Internal Medicine of Bir Hospital from $1^{\text {st }}$ March 2016 to $28^{\text {th }}$ February 2017. Ethical approval was taken from the institutional review board of the institute. All patients with clinical, radiological, or sonographic evidence of pleural effusion were included after written informed consent. Patients with pleural effusion secondary to trauma, with hydropneumothorax and who refused to give consent were excluded from the study.

Patients admitted to the medical ward of Bir Hospital with clinical signs and symptoms of pleural effusion were evaluated and enrolled after taking the informed consent. A chest x-ray was performed for each patient. Investigations like USG of the chest in case of minimal or suspected pleural effusion on chest X-ray were done as appropriate.

Those patients with pleural effusion had then undergone thoracentesis. $10 \mathrm{ml}$ of pleural fluid was obtained by a disposable plastic syringe maintaining all aseptic precautions in inpatient settings. The sample of pleural fluid thus obtained was sent immediately and those samples not feasible to send immediately to the laboratory for analysis were refrigerated until analysis was done within 24 hours of sample collection. The pleural fluid was analyzed for total protein, $\mathrm{LDH}$, glucose, TC, DC, malignant cells, ADA, Gram's stain, AFB stain, bacterial culture, and cholesterol level along with simultaneous blood samples for LDH and total protein. A blood sample was also sent for other routine investigations like TC, DC, Hb, ESR, RFT and electrolytes. Other investigations like sputum for AFB, sputum culture, sputum for malignant cell, bilirubin, SGPT, SGOT, ECG, Echocardiography, contrast-enhanced CT of the chest, Bronchoscopy and biopsy, Ultrasound of abdomen and pelvis were done as indicated according to the history and physical examination findings. The final diagnosis was made based on clinical judgment and supportive investigations.

All investigations were recorded in the tabulated proforma. The best cutoff value for pleural fluid cholesterol $>60 \mathrm{mg} / \mathrm{dL}$ was calculated using the ROC curve with area under the curve (AUC) of 0.968 and sensitivity of $86.9 \%$ and zero false-positive rates. Pleural fluid cholesterol $>60 \mathrm{mg} / \mathrm{dL}$ and protein $>3 \mathrm{~g} / \mathrm{dL}$ were taken to classify pleural fluid as exudates in this study. It was compared with the diagnosis on discharge. The statistical significance of Light's criteria was measured and compared with the diagnosis on discharge to find out their usefulness in categorizing the pleural effusions. All the data were entered using Microsoft Excel version 2007. Statistical analysis was done using SPSS 20.0. Normally distributed data were expressed as mean \pm standard deviation and categorical variables as numbers and frequencies. A Chi-square test was used for comparison between the groups.

\section{RESULTS}

A total of 81 patients with pleural effusion were enrolled in this study. There was male predominance with $42(51.9 \%)$ out of total. The mean age of the patient was $45.88 \pm 18.25$ years. Most patients with pleural effusion belong to the age group of 2535 years. 43 patients were smokers of which 25 (58.1\%) were male. $12(14.8 \%)$ were found to be alcohol consumption, among them, $8(66.6 \%)$ were male and $4(33.3 \%)$ were female. The most common cause of pleural effusion was tuberculosis, followed by dilated cardiomyopathy (DCM), Malignancy, and Parapneumonic effusion. (Table 1) The least common causes included were Empyema thoracic, hepatic hydrothorax, Nephrotic syndrome, and pancreatic pleural effusion. Such wise, fever, chest pain, cough were the most common signs and symptoms as shown in table 1 . Light's criterion had a sensitivity and specificity of $96.6 \%$ and $30.4 \%$ respectively with a significant $p$-value of $<0.001,95 \%$ CI: 0.8-0.95. (Table 2)

Comparing pleural fluid cholesterol $>60 \mathrm{mg} / \mathrm{dL}$ and protein $>3 \mathrm{~g} / \mathrm{dL}$ with the clinical diagnosis to differentiate exudative and transudative pleural effusions, it classified 51/ 58 exudates correctly whereas 7 were misclassified as transudates. All transudates were correctly classified by these criteria. It had sensitivity and specificity of $87.9 \%$ and $100 \%$ respectively with a significant $p$-value of $<0.001,95 \%$ CI: $0.515-0.734$. (Table 3) 
NEPALESE MEDICAL JOURNAL issue 5 | vol 3 | 2020

Table 1: Major presenting symptoms/signs in different diagnosis on the discharge of the study population

\begin{tabular}{|c|c|c|c|c|c|c|c|c|}
\hline $\begin{array}{l}\text { Diagnosis } \\
\text { Symptoms/ } \\
\text { Signs }\end{array}$ & $\begin{array}{c}\text { TB Pleural } \\
\text { Effusion }(n=37)\end{array}$ & $\operatorname{DCM}(n=18)$ & $\begin{array}{l}\text { Malignancy } \\
\qquad(\mathrm{n}=9)\end{array}$ & $\begin{array}{c}\text { Parapneumonic } \\
\text { Effusion } \\
(\mathbf{n}=7)\end{array}$ & $\begin{array}{c}\text { Empyema } \\
\text { Thoracic } \\
(n=4)\end{array}$ & $\begin{array}{c}\text { Hepatic } \\
\text { Hydrothorax } \\
(n=4)\end{array}$ & $\begin{array}{c}\text { Nephrotic } \\
\text { Syndrome } \\
\quad(n=1)\end{array}$ & $\begin{array}{c}\text { Pancreatic } \\
\text { Pleural } \\
\text { effusion }(n=1)\end{array}$ \\
\hline Fever & $29(78.3 \%)$ & $6(33.3 \%)$ & $1(11.1 \%)$ & $4(57.1 \%)$ & $4(100 \%)$ & $0(0 \%)$ & $0(0 \%)$ & $0(0 \%)$ \\
\hline Chest Pain & $26(70.2 \%)$ & $8(44.4 \%)$ & $8(88.9 \%)$ & $5(71.4 \%)$ & $4(100 \%)$ & $4(100 \%)$ & $0(0 \%)$ & $1(100 \%)$ \\
\hline Cough & $26(70.2 \%)$ & $14(77.8 \%)$ & $9(100 \%)$ & $5(71.4 \%)$ & $4(100 \%)$ & $2(50 \%)$ & $0(0 \%)$ & $0(0 \%)$ \\
\hline Hemoptysis & $2(5.4 \%)$ & $0(0 \%)$ & $6(66.6 \%)$ & $0(0 \%)$ & $0(0 \%)$ & $0(0 \%)$ & $0(0 \%)$ & $0(0 \%)$ \\
\hline Dyspnea & $18(48.6 \%)$ & $18(100 \%)$ & $5(55.5 \%)$ & $5(71.4 \%)$ & $2(50 \%)$ & $2(50 \%)$ & $0(0 \%)$ & $1(100 \%)$ \\
\hline $\begin{array}{l}\text { Poor } \\
\text { Appetite }\end{array}$ & $2(5.4 \%)$ & $2(11.1 \%)$ & $3(33.3 \%)$ & $0(0 \%)$ & $0(0 \%)$ & $0(0 \%)$ & $0(0 \%)$ & $0(0 \%)$ \\
\hline $\begin{array}{l}\text { Weight } \\
\text { Loss }\end{array}$ & $2(5.4 \%)$ & $1(5.5 \%)$ & $4(44.4 \%)$ & $0(0 \%)$ & $0(0 \%)$ & $0(0 \%)$ & $0(0 \%)$ & $0(0 \%)$ \\
\hline Edema & $1(2.7 \%)$ & $12(66.6 \%)$ & $0(0 \%)$ & $0(0 \%)$ & $0(0 \%)$ & $4(100 \%)$ & $1(100 \%)$ & $0(0 \%)$ \\
\hline Pallor & $0(0 \%)$ & $0(0 \%)$ & $3(33.3 \%)$ & $1(14.2 \%)$ & $0(0 \%)$ & $4(100 \%)$ & $0(0 \%)$ & $0(0 \%)$ \\
\hline Icterus & $0(0 \%)$ & $0(0 \%)$ & $0(0 \%)$ & $0(0 \%)$ & $0(0 \%)$ & $4(100 \%)$ & $0(0 \%)$ & $0(0 \%)$ \\
\hline $\mathrm{LN}^{*}$ & $0(0 \%)$ & $0(0 \%)$ & $4(44.4 \%)$ & $0(0 \%)$ & $0(0 \%)$ & $0(0 \%)$ & $0(0 \%)$ & $0(0 \%)$ \\
\hline JVP** & $1(2.7 \%)$ & $7(38.9 \%)$ & $0(0 \%)$ & $0(0 \%)$ & $0(0 \%)$ & $0(0 \%)$ & $0(0 \%)$ & $0(0 \%)$ \\
\hline Clubbing & $2(5.4 \%)$ & $0(0 \%)$ & $5(55.5 \%)$ & $0(0 \%)$ & $0(0 \%)$ & $4(100 \%)$ & $0(0 \%)$ & $0(0 \%)$ \\
\hline
\end{tabular}

*Lymphadenopthy; ** Jugular venous pressure

Table 2: Relationship between Light's criteria and diagnosis on discharge.

\begin{tabular}{|c|c|c|c|c|}
\hline & & & at discharge & \\
\hline & & Exudate & Transudate & Iotal \\
\hline - & Exudate & $56(96.6 \%)$ & $16(69.6 \%)$ & $72(88.9 \%)$ \\
\hline Ligmt s C ritena & Transudate & $2(3.4 \%)$ & $7(30.4 \%)$ & $9(11.1 \%)$ \\
\hline Total & & $58(100.0 \%)$ & $23(100.0 \%)$ & $81(100.0 \%)$ \\
\hline
\end{tabular}

Table 3: Relationship of Pleural fluid cholesterol and/or protein level with the diagnosis on discharge

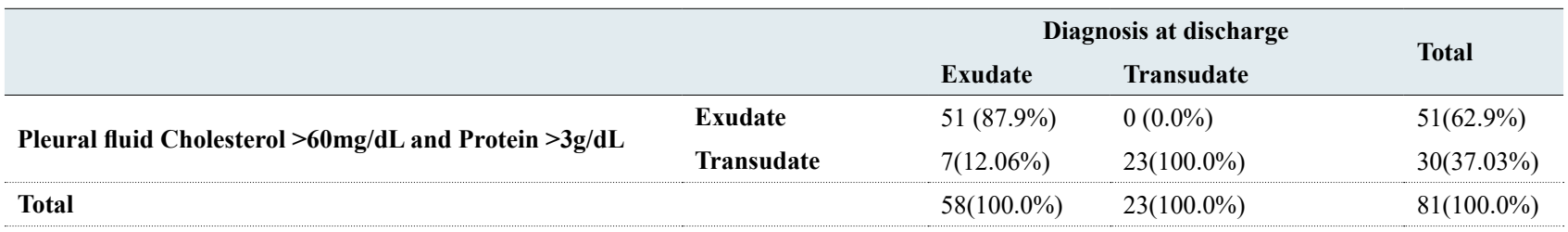

\section{DISCUSSION}

Mean age of the patient with pleural effusion in our study was $45.88 \pm 18.25$ and most patients belong to the age group of 25-35, which was similar to a study done in Kathmandu Medical College by Dhital, K. et al.7 The most common cause of exudative pleural effusion was tuberculosis followed by malignancy in a study done by Liam CK et al. ${ }^{8}$ Other studies done in $\mathrm{Nepal}^{7,9}$ found the most common cause of exudative pleural effusion being tuberculosis. All of the above study findings were similar to the finding of our study.

Comparing Light's criteria with the diagnosis on the discharge of our study, it correctly classified 56 out of $58(96.6 \%)$ exudates and it had sensitivity and specificity of $96.6 \%$ and $34.4 \%$ respectively. The sensitivity of Light's criteria was $98 \%$ with a study done in South Africa Tygerberg Hospital9 which was comparable to our study. The result of a study done by Patel AK et al6 was also comparable to our study with a sensitivity of $98 \%$.
The specificity of comparing pleural fluid cholesterol $>60 \mathrm{mg} /$ $\mathrm{dL}$ and protein $>3 \mathrm{~g} / \mathrm{dL}$ with the clinical diagnosis to differentiate exudative and transudative pleural effusion, a study done in India by Patel AK et alS6 was $100 \%$, which was comparable to our study. However, the sensitivity (100\%) was inconsistent.

\section{CONCLUSIONS}

Though Light's criteria remain the gold standard to differentiate transudative and exudative pleural effusion, combined pleural fluid cholesterol and total protein give nearly comparable results without the need for simultaneous blood investigations. So to omit the need for simultaneous blood sampling and simplify the diagnostic procedure, combined pleural fluid cholesterol and total protein can be used as an alternative to Light's criteria in resource-limited setting. However larger studies are needed to make definite conclusions. 


\section{REFERENCES}

1. Light RW. Disorder of the Pleura and Mediastinum. In: Kasper DL, Fauci AS, Longo DL, Braunwald E, Hauser SL, Jameson JL, eds. Harrison's Principles of Internal Medicine. 20th ed. New York, NY: McGraw-Hill; 2006. 2009p.

2. Light RW, Macgregor I, Luchsinger PC, Ball WC. Pleural effusions: the diagnostic separation of transudates and exudates. Ann Intern Med 1972; 77 (4):507-13 Crossref

3. Romero-Candeira S, Fernández C, Martín C, Sánchez-Paya J, Hernández L. Influence of diuretics on the concentration of proteins and other components of pleural transudates in patients with heart failure. Am. J. Med. 2001;110(9):681-6. Crossref

4. Valdés L, Pose A, Suàrez J, Gonzalez-Juanatey JR, Sarandeses A, San José E, et al. Cholesterol: a useful parameter for distinguishing between pleural exudates and transudates. Chest. 1991;99(5):1097102. Crossref

5. Hamm H, Brohan U, Bohmer R, Missmahl HP. Cholesterol in pleural effusions: a diagnostic aid. Chest. 1987;92(2):296-302. Crossref
6. Patel AK, Choudhury S. Combined pleural fluid cholesterol and total protein in differentiation of exudates and transudates. Indian J Chest Dis Allied Sci 2013;55(1):21-3. Website

7. Dhital KR, Acharya R, Bhandari R, Kharel P, Giri KP, Tamrakar $\mathrm{R}$. Clinical profile of patients with pleural effusion admitted to KMCTH. Kathmandu University Medical Journal. 2009;7(4):43844. Crossref

8. Liam CK, Lim KH, Wong CM. Causes of pleural exudates in a region with a high incidence of tuberculosis. Respirology. 2000;5(1):33-8. Crossref

9. Hamal AB, Yogi KN, Bam N, Das SK, Karn R. Pleural fluid cholesterol in differentiating exudative and transudative pleural effusion. Pulmonary medicine. 2013, Article ID 135036, 4 pages. Crossref

10. Burgess LJ, Maritz FJ, Taljaard JF. Comparative analysis of the biochemical parameters used to distinguish between pleural transudates and exudates. Chest. 1995;107(6):1604-9. Crossref 